\title{
Metil Paration’nun Piruvat Kinaz Enzim Aktivitesine Etkisi
}

\author{
Egemen DERE ${ }^{1}$, Ferda ARI ${ }^{1} \&$ \\ ${ }^{1}$ Biyoloji Bölümü, Fen-Edebiyat Fakültesi, Bursa Uludağ Üniversitesi, Bursa, Türkiye \\ $\triangle$ : ferdaoz@uludag.edu.tr, (iD)10000-0001-9572-1051, (D)2 0000-0002-6729-7908
}

Geliş (Received): 10.12.2020Ｄüzeltme (Revision):05.02.2021～Kabul (Accepted): 21.02.2021

\begin{abstract}
$\ddot{O Z Z}$
Metil paration, tarımda ve genel alanlarda zararlılara karşı kullanılan organofosfat grubu bir insektisittir. İnsektisitlerin çevre ve canlı organizmalar üzerinde önemli derecede toksik etkileri bulunmaktadır. İnsanlarda farklı toksisiteye neden olan Metil paration'un metabolizmayı kontrol eden önemli enzimleri etkilediği bilinmektedir. Allosterik özellik gösteren Piruvat kinaz (EC.2.7.1.40), glikolizin son enzimidir ve glikoliz ile devamındaki moleküler yolaklarda kontrolü sağlamaktadır. Çalışmamızda Metil paration'nun Piruvat kinaz enzim aktivitesi üzerine etkisi araştırıldı. Metil paration'un $\mathrm{LD}_{50}$ dozu $(7 \mathrm{mg} . \mathrm{kg}-1)$ intraperitoneal olarak farklı periyotlarla $(2,4,8$, 16, 32, 64 ve 72 saat) erkek ve dişi sıçanlara uygulandı. Sıçanların karaciğer, böbrek, beyin ve ince bağırsak dokularında Piruvat kinaz enzim aktivitesi analiz edildi. Metil paration maruziyeti sonucunda sıçan dokularında genel olarak Piruvat kinaz enzim aktivitesinde artışlar belirlendi. Bu aktivasyonların özellikle beyin dokusunda daha erken saatlerde gerçekleşmiş olması dikkat çekicidir. Karaciğer, böbrek ve ince bağırsak dokularında aktivasyonların dişilerde erkeklerden daha erken saatlerde olduğu gözlendi. Sonuç olarak bir insektisit olan Metil paration uygulamasının sıçan dokularında piruvat kinaz enzim aktivitesinde artışlara neden olduğu bulundu. Metil parationun glikoz metabolizmasını ve buna bağlı olarak diğer metabolik yolakları etkilediği tartışıldı. Bu nedenle Metil paration insektisitinin metabolizmayı etkilediği, farklı sağlık sorunlarına neden olabileceği düşünülmeli ve Dünya Sağlık örgütünün önerdiği uygulama dozuna dikkat edilerek güvenli kullanım için önlemler alınmalıdır.
\end{abstract}

Anahtar Kelimeler: İnsektisit, Piruvat kinaz, Metil paration

\section{The Effect of Methyl Parathion on The Pyruvate Kinase Enzyme Activity}

\begin{abstract}
Methyl parathion is an organophosphate group insecticide used against pests in agriculture and general fields. Insecticides have a significant toxic effect on the environment and living organisms. Methyl parathion, which causes different toxicity in humans, is also known to affect important enzymes that control metabolism. Pyruvate kinase that allosteric properties (EC.2.7.1.40) is the last enzyme of glycolysis and provides control in glycolysis followed by molecular pathways. In our study, the effect of Methyl parathion on Pyruvate kinase enzyme activity was investigated. Methyl parathion $\mathrm{LD}_{50}$ dose (7mg.kg-1) was administered intraperitoneally to male and female rats at different periods $(2,4,8,16,32,64$ and 72 hours). Pyruvate kinase enzyme activity was analyzed in liver, kidney, brain and small intestine tissues of rats. As a result of exposure of Methyl parathion, increases in Pyruvate kinase enzyme activity were generally determined in rat tissues. It was remarkable that the activations took place earlier, especially in the brain tissue. It was observed that these activations in liver, kidney and small intestine tissues were earlier in females than in males. As a result, the application of Methyl parathion was found to cause increases in pyruvate kinase enzyme activity in rat tissues. It was determined that methyl parathion affects glucose metabolism and the other metabolic pathways. Therefore, it should be considered that methyl parathion insecticide affects metabolism and may cause different health problems and precautions should be taken in use by paying attention to the application dose recommended by the World Health Organization.
\end{abstract}

Key words: Insecticide, Methyl parathion, Pyruvate kinase

\section{GíRiş}

Pestisitler özellikle gıda ve tarım alanlarında zararlılara karşı kullanılan maddelerdir. Çok geniş kullanım alanına sahip olan pestisitlerin, artan nüfusa bağlı olarak dünya genelinde kullanım oranı da artmaktadır. Pestisit kullanımının dünya genelinde 1990-2017 verilerine göre 4,5 milyon tona ulaştığ 1 bildirilmektedir [1]. Ülkemizde 2002-2017 yılında yapılan istatistiklerde pestisit kullanımı 2017 yılında 54 bin tona ulaştığ görülmektedir. Bursa ilimizde ise toplam pestisit kullanımının 2.994,365 (kg-lt) olduğu ve pestisitlerin içinde insektisit kullanımın 763.293 (kg-lt) olduğu belirlenmiştir [2]. Pestisitlerin bu kadar fazla kullanımının insan sağlığını olumsuz yönde etkilediği de bilinmektedir. Pestisitler kimyasal formüllerine göre farklı sinıflara ayrilırlar. Bu sinıflardan biri de fosfat grubu içeren organofosfatlı pestisitlerdir. $\mathrm{Bu}$ sınıfin çoğunluğunu insektisitler oluşturmaktadırlar. Organofosfatlı insektisitler hem tarımsal hem de genel alanlarda sıklıkla zararlılara karşı kullanılmaktadırlar. İnsektisitlerin bilinçsiz şekilde kullanımları hem çevreyi 
hem de canlı organizmaları etkilemektedir [3]. Metil paration (O,O-dimetil O-4-nitrofenil fosforotioat; MP) I. sinıf toksik grubunda yer alan organofosfatlı insektisittir [4]. Canlılar MP'a, ya toprağa/suya karıșması ya da mesleki maruriyet nedeniyle maruz kalmaktadırlar. $\mathrm{Bu}$ toksik maddenin düzensiz kullanılması organizmalar ve çevre üzerinde zararlı etkilere neden olmaktadır [5]. Yapılan çalışmalarda karaciğer, böbrek ve beyin gibi dokularda toksisiteye neden olduğu gösterilmiştir [6, 7]. Ayrıca bu insektisit canlı sistemlerde spesifik enzimleri içeren metabolik yolakları da etkileyebilmektedir [810]. Yine MP'nin oksidatif strese, DNA hasarına ve genotoksik etkilere neden olduğu da göstermiştir [1113]. Piruvat kinaz (PK) (EC.2.7.1.40), glikolizin son aşamasında yer alan fosfat grubunun fosfoenolpiruvat (PEP)'dan adenosin difosfat (ADP)'a aktarılmasıly piruvat ve adenosin trifosfat (ATP) oluşumunu katalizleyen allosterik bir enzimdir [14]. PK enzimi, glikoliz ve özellikle de glikolizin devamındaki metabolik yolakların kontrolü için kritik öneme sahiptir. PK, aktivitesi için monovalent $\left(\mathrm{K}^{+}\right)$ve iki değerlikli katyonlara $\left(\mathrm{Mg}^{+2}\right.$ veya $\left.\mathrm{Mn}^{+2}\right)$ ihtiyaç duymaktadır. Tepkime fizyolojik koşullar altında geri döndürülemez olarak gerçekleşmektedir. Ayrıca, oluşan Piruvat çeşitli metabolik yollarda kullanılmaktadır. Hücresel metabolizmada böyle merkezi bir pozisyonda olması PK'nın metabolizmadaki önemini göstermektedir [15]. Çalışmamızda tarımsal alanlarda sıklıkla kullanılan MP'nin glikoliz yolağında kontrol görevi olan PK enzim aktivitesine olan etkisi araştırılmıştır. Erkek ve dişi sıçanların MP maruziyeti sonrasında karaciğer, böbrek, beyin ve ince bağırsak dokularında PK aktivitesi değerlendirilmiş ve tüm dokularda PK aktivasyonları kaydedilmiştir.

\section{MATERYAL ve YÖNTEM}

Bu çalışmada öncelikle 200-250 g ağırlığında olan Rattus norvegicus sıçanları kontrol grubunda 2 erkek ve 2 dişi; MP uygulanan grup 4 erkek ve 4 dişi olacak şekilde ayrılarak planlanmıştır. Tüm analizler için toplam 84 hayvan kullanılmıştır. Siçanlar Bursa Uludağ Üniversitesi Deney Hayvanları Besleme ve Araştırma Merkezi'nden temin edilmiştir. Bursa Uludağ Üniversitesi Hayvan Bakım ve Kullanım Komitesi, çalışmamıza etik kurul raporu vermiştir (3.06.2003/3). Deney grubuna MP'nin $7 \mathrm{mg} \mathrm{kg}^{-1}\left(\mathrm{LD}_{50}\right) \mathrm{MP}$ dozu, kontrol grubuna ise mısır yağı intraperitonal olarak enjekte edilmiştir. Hayvanlar belirlenen zaman periyotlarından $(2,4,8,16,32,64$ ve 72 saat) sonra servikal dislokasyon yolu ile öldürüldükten sonra dokular çıkarılmış ve homojenize edilmiştir. Homojenatlar 48000 g'de 30 dak $4^{\circ} \mathrm{C}$ de santrifüj edilerek süpernatantlar enzim kaynağı olarak kullanılmıştır. Fosfoenolpirüvattaki fosfat grubunu ADP'ye aktararak ATP ile pirüvat meydana gelmesini sağlayan PK aktivitesi, meydana gelen pirüvatın laktat dehidrogenez (LDH) aktivitesi ile laktata dönüşümü esnasında kullanılan NADH'ın azalan absorbans hızının 340nm dalga boyunda kinetik olarak ölçülmesiyle hesaplanmıştır. Aktivite deneyleri optimum koşullarda
$1 \mathrm{~cm}$ 'lik kuvars spektrofotometre küvetleri içinde gerçekleştirilmiş ve azalan absorbans değerleri $5 \mathrm{dk}$ boyunca takip edilmiştir. Elde edilen veriler $\mathrm{U} / \mathrm{mg}$ protein olarak hesaplanmıştır [16]. Protein derişimleri, Bradford (1976) yöntemi kullanılarak belirlenmiştir [17].

Tüm istatistiksel analizler GraphPad Prism 8.0 (Demo Versiyonu; GraphPad, San Diego, CA) programı kullanılarak yapıldı. Deneyin sonuçları, verilerin ortalaması hesaplanarak $\pm \mathrm{SH}$ (standart hata) olarak sunulmuştur. Anlamlılık, iki yönlü varyans analizi kullanılarak hesaplanmıștır. $\mathrm{P}<0.05, \mathrm{P}<0.01$ ve $\mathrm{P}$ $<0.001$ değerleri istatistiksel olarak anlamlı olarak kabul edilmiştir.

\section{BULGULAR}

Metil Paration'nun Karaciğer Dokusunda Piruvat Kinaz Aktivitesi Üzerine Etkisinin Değerlendirilmesi Karaciğer dokularında MP'nin PK enzim aktivitesine etkisi değerlendirildiğinde; erkek sıçanlarda PK aktivitesinin 32 ve 64 . saatlerde kontrol grubuna göre istatistiksel olarak anlamlı bir şekilde arttığ belirlenmiştir $(\mathrm{p}<0.05, \mathrm{p}<0.001$; Şekil 1A). PK aktivite artışının 72. saatte azaldığı görülmektedir. Dişi sıçanlarda ise PK aktivitesinin daha erken saatlerde arttığı ve bu artışın 4. saatten itibaren anlamlı şekilde yükseldiği belirlenmiştir. PK aktivite artışının en yüksek 8. saatte olduğu da dikkati çekmektedir. $\mathrm{Bu}$ saatten itibaren PK aktivitesinde bir azalma olsa da aktivasyonun deney periyodu sonuna kadar devam ettiği görülmüştür ( $\mathrm{p}<0.05, \mathrm{p}<0.01$; Şekil 1B).

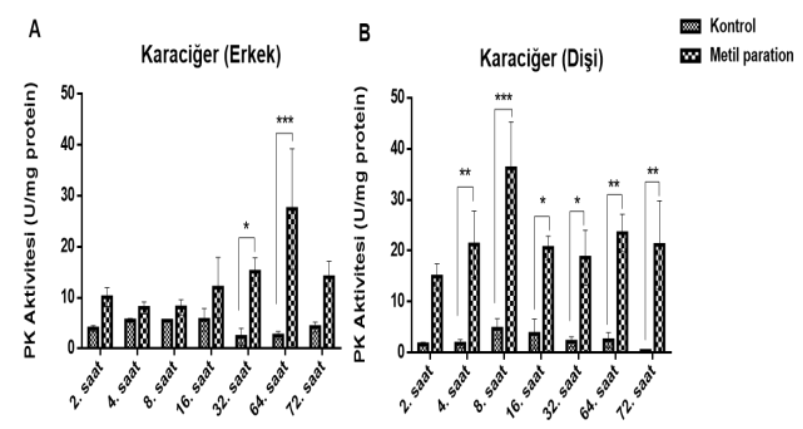

Şekil 1. Metil Paration'nun erkek (A) ve dişi (B) sıçanların karaciğer dokusunda Piruvat Kinaz (PK) aktivitesi (U/mg.protein) üzerine etkisi. *Kontrole klyasla istatistiksel olarak anlamlı farklılıkları belirtir $*(\mathrm{p}<0.05) ; * *(\mathrm{p}<0.01)$; $* * *(\mathrm{p}<0.001)$. Verilerin ortalamas1 ve standart hataları hesaplanarak verilmiştir $(n=3)$.

Metil Paration'nun Böbrek Dokusunda Piruvat Kinaz Aktivitesi Üzerine Etkisinin Değerlendirilmesi MP'nin böbrek dokularında PK enzim aktivitesinde kontrol grubuna kiyasla genel olarak bir aktivasyona neden olduğu belirlenmiştir. $\mathrm{Bu}$ aktivasyon erkek sıçanlarda 8. saatte istatistiksel olarak anlamlı bir şekilde artmışken $(p<0.05$, Şekil 2A), dişi sıçanlarda 4. ve 8 . saatlerde istatistiksel olarak anlamlı olduğu belirlenmiştir ( $\mathrm{p}<0.05 ; \mathrm{p}<0.001$, Şekil 2B). PK aktivite artışının hem dişi hem erkek sıçanlarda en yüksek 8 . 
saatte olduğu gözlenmiştir. 8. saatten itibaren PK aktivitesinde bir azalma olsa da aktivasyonun deney periyodu sonuna kadar devam ettiği görülmüştür (Şekil $2 \mathrm{~A}$ ve $\mathrm{B})$.

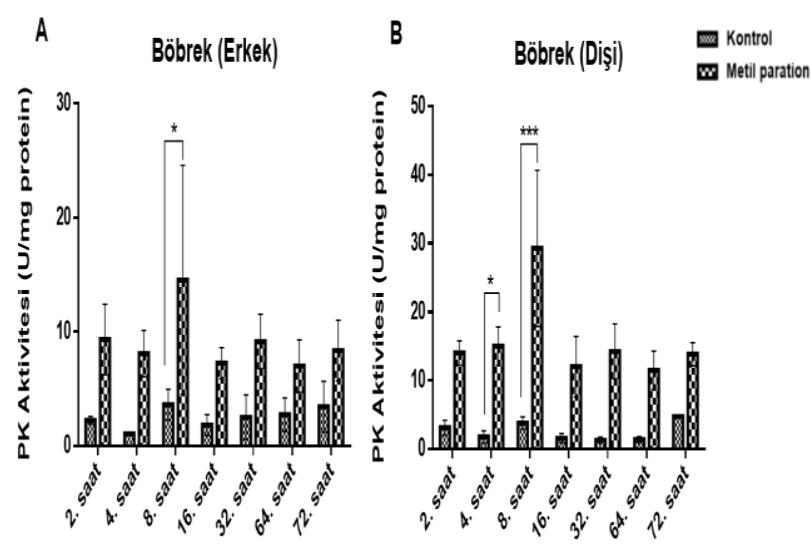

Şekil 2. Metil Paration'nun erkek (A) ve dişi (B) sıçanların böbrek dokusunda Piruvat Kinaz (PK) aktivitesi (U/mg.protein) üzerine etkisi. *Kontrole kıyasla istatistiksel olarak anlamlı farkl1likları belirtir $*(\mathrm{p}<0.05) ; * *(\mathrm{p}<0.01)$; $* * *(p<0.001)$. Verilerin ortalamas1 ve standart hatalar1 hesaplanarak verilmiştir $(n=3)$.

Metil Paration'nun Beyin Dokusunda Piruvat Kinaz Aktivitesi Üzerine Etkisinin Değerlendirilmesi

PK enzim aktivitesine MP'nin etkisi beyin dokularında araştırıldığında; deney periyotlarının tümünde kontrol grubuna göre bir artış gözlenmiş̧iir. Erkek ve dişi sıçanlarda erken dönemden (2. saat) aktivasyonun başladığı dikkat çekicidir. Erkek sıçanlarda beyin PK aktivitesinin $2,4,8$ ve 32 . saatlerde istatistiksel olarak anlamlı bir şekilde arttığı $(p<0.05, p<0.01$; Şekil 3A), en yüksek aktivite artışının 4. saatte olduğu görülmüştür. Dişi sıçanlarda beyin PK aktivitesinin ise 8, 16 ve 64 . saatlerde istatistiksel olarak anlamlı olduğu $(p<0.05 ; p$ $<0.01 ; \mathrm{p}<0.001$, Şekil 3B), en yüksek PK aktivitesinin 8. saatte ortaya çıktığı kaydedilmiştir.

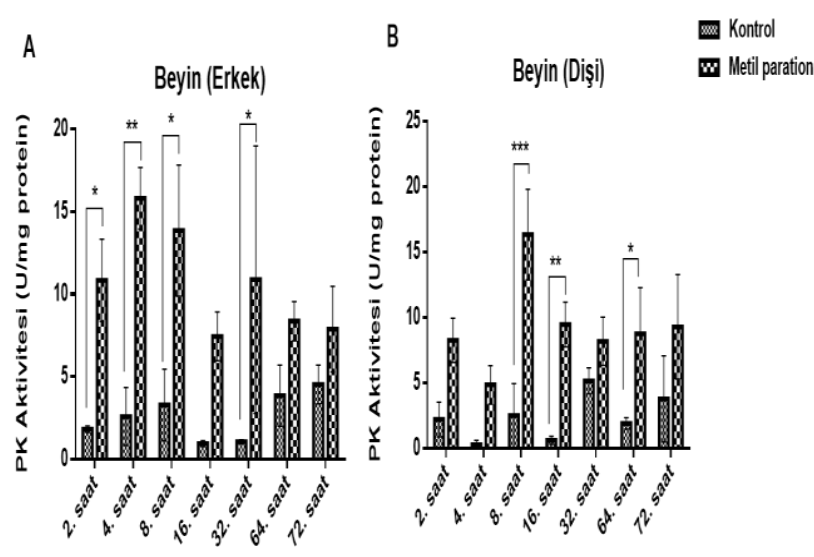

Şekil 3. Metil Paration'nun erkek (A) ve dişi (B) sıçanların beyin dokusunda Piruvat Kinaz (PK) aktivitesi (U/mg.protein) üzerine etkisi. *Kontrole kıyasla istatistiksel olarak anlamlı farkl11ıklar1 belirtir $*(\mathrm{p}<0.05) ; \quad * *(\mathrm{p}<0.01) ; \quad * * *(\mathrm{p}<0.001)$.
Verilerin ortalaması ve standart hataları hesaplanarak verilmiştir $(\mathrm{n}=3)$.

\section{Metil Paration'nun İnce Bağırsak Dokusunda Piruvat Kinaz Aktivitesi Üzerine Etkisinin Değerlendirilmesi}

MP'nin ince bağırsak dokularında erkek ve dişi PK enzim aktivitesinde ilk periyotlarda (4 ve 8 . saat) kontrol grubuna göre aktivasyonlar gözlenmiştir. PK aktivitesindeki artışın sıçanlarda 4 ve 8 . saatlerde istatistiksel olarak anlamlı olduğu belirlenmiştir (p $<0.05 ; \mathrm{p}<0.01 ; \mathrm{p}<0.001$, Şekil 4 A ve $\mathrm{B})$. 8. saatten itibaren ince bağırsak PK aktivitesinde deney periyodu sonuna kadar azalmalar gözlenmiştir (Şekil 4A ve B).

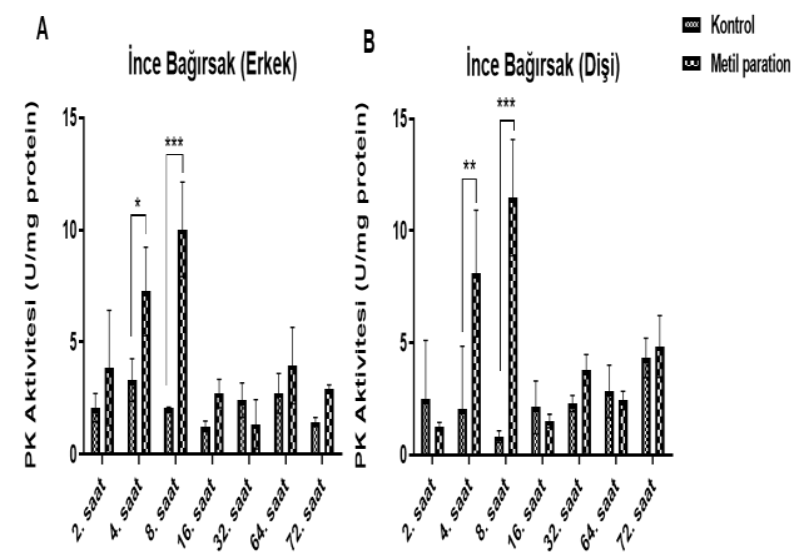

Şekil 4. Metil Paration'nun erkek (A) ve dişi (B) sıçanların ince bağırsak dokusunda Piruvat Kinaz (PK) aktivitesi (U/mg.protein) üzerine etkisi. *Kontrole kiyasla istatistiksel olarak anlamlı farkl11ıkları belirtir $*(\mathrm{p}<0.05) ; * *(\mathrm{p}<0.01)$; $* * *(\mathrm{p}<0.001)$. Verilerin ortalamas1 ve standart hatalar1 hesaplanarak verilmiştir $(\mathrm{n}=3)$.

\section{TARTIŞMA ve SONUÇ}

Tarımda verimi arttırmak için pestisit kullanımı önemli bir yaklaşımdır. Ancak pestisitlerin bilinçsiz bir şekilde kullanımı insanlar, hayvanlar ve çevre üzerine olumsuz etkilere neden olmaktadır [18, 19]. MP, aşırı toksik olarak sınıflandırılmasına rağmen, birçok ülkede halen kullanılan organofosfatlı bir insektisittir [4, 20]. MP'nin insektisidal aktivitesi deri, oral ya da solunum yoluyla gerçekleşmektedir [21]. Yapılan çalışmalarda MP'nin hepatotoksik, nörotoksik ve genotoksik etkilere neden olduğu belirlenmiştir [22, 11, 23]. Canlıları doğrudan ya da dolaylı olarak etkileyen MP'nin hücresel sistemde enzimleri de etkilediğini gösteren çalışmalar vardır [24, $9,10]$.

İnsektisitler başlıca kas ve sinir sistemleri olmak üzere büyümeyi, gelişmeyi ve enerji üretimini etkilemektedir [25]. Çalışmamızda MP'nin, glikolitik yolun önemli kontrol enzimlerinden biri olan PK aktivitesine olan etkisi farklı dokularda (karaciğer, böbrek, beyin ve ince bağırsak) incelenmiştir. Aldığımız sonuçlarda MP'nin dokularda PK aktivitesinde aktivasyona neden olduğu belirlenmiştir. Karaciğer dokusunda PK aktivasyonu dişi sıçanlarda erken dönemlerde $(2,4$ ve 8 . saat) iken erkek sıçanlarda ise daha geç dönemlerde (32 ve 6 . saat) istatistiksel olarak anlamlı bir şekilde arttığ1 
belirlenmiştir. Daha öncede yapılan bir çalışmada MP'nin sıçan karaciğer enzimleri olan ve karaciğer hasarını gösteren aspartat amino transferaz (AST), alanin aminotransferaz (ALT) ve laktat dehidrogenaz (LDH) enzim aktivitelerinde artışa neden olduğu gösterilmiştir [23]. Yine MP'ye maruz kalan bir işçide yapılan analizlerde MP'nin karaciğer ve böbrek toksisitesine neden olduğu belirlenmiştir [6]. Çalışmamızda böbrek dokusunda PK aktivitesinin 8 . saate kadar arttığı daha sonraki saatlerde ise aktivasyon seviyesinin azaldığı görülmektedir. Fakat genel anlamda PK aktivitesinde kontrole göre aktivasyonların deney periyodunun sonuna kadar devam ettiği belirlenmiştir.

Beyin ve ince bağırsak dokularında da benzer şekilde MP'nin PK aktivitesinde aktivasyona neden olduğu bulunmuştur. PK aktivasyonunun 8 . saate doğru maksimum seviyeye ulaştığı daha sonra aktivasyonda azalmalar meydana geldiği gözlenmiştir. Daha önce grubumuz tarafindan farklı bir pestisit olan 2,2diklorovinil dimetil fosfat (DDVP) ile yaptı̆̆ımız çalışmada DDVP'nin sıçan dokularında PK aktivitesinde artışına neden olduğu da belirlenmişti [26]. Farklı bir çalışmada 2,3,7,8-tetraklorodibenzo-pdioksin'nin (TCDD) siçanlarda hepatotoksisiteye neden olduğu ve karaciğer PK enzim artışına neden olduğu belirlenmiştir [27]. Papadopoulos ve ark. yaptıkları çalışmada da MP'nin böceklerde kullanıldığında PK aktivitesinde artışa neden olduğunu göstermişlerdir [28]. Yine MP'nin hayvan dokularında katalaz (CAT), glutatyon peroksidaz (GPx), süperoksit dismutaz (SOD) gibi enzimlerin aktivasyonuna da neden olduğu belirtilmiştir [29]. Farklı bir çalışmada da MP'nun CAT ve Glutatyon redüktaz (GSSG-R) enzimlerinde anlamlı artışlar belirlenmiştir [10]. Sadece MP değil yapılan çalışmalarda farklı pestisitlerin de bazı glikolitik yolak enzimlerinde artışa neden olduğu belirlenmiştir [30-32]. Tüm bu çalışmalar MP'nun metabolizmada hücresel enzimleri etkilediğini göstermektedir. Nitekim bizde çalışmamız sonucunda MP'nun genel olarak dokularda PK aktivitesinin artışına neden olduğu gözlenmiştir. Hücrede metabolik yolakların birbiri ile ilişkili oldukları düşünüldüğünde PK aktivitesindeki bu artışın diğer metabolik yolakları da etkileyeceği açıktır. Özellikle PK aktivitesinde olabilecek bir artış PK'nın katalizlediği tepkime ürünü olan piruvatın artışına neden olacaktır. Piruvat hücresel metabolizmada merkezi bir rol alan ve pek çok metabolik yolun geçekleşmesi için gerekli regülatör bir proteindir [15]. Sitoplazmada oluşan piruvat mitekondriye taşınarak burada ATP oksidatif fosforilasyon ile enerji üretimine ve pekçok biyosentetik yolağın gerçekleşmesine neden olmaktadır. Herhangi bir nedenle artan pirüvat metabolizması enerji metabolizmasının değişmesine neden olacak ve özellikle beyin gibi ATP'ye bağımlı organlar daha fazla etkilenecektir. Bu durum kanser, kalp rahatsızlıkları ve nörodejeneratif hastalıklara neden olabilmektedir [33]. $\mathrm{Bu}$ yüzden $\mathrm{PK}$ artışının tüm metabolik yolakları da etkileyeceği açıktır. Bu nedenle çalışmamızda MP'nun enerji metabolizmasında etkili olan PK aktivitesine etkisini araştırıldı. Sonuç olarak, çalışmamızda MP toksisitesinin glikoz metabolizmasında özellikle piruvat kinaz enzim aktivitesinde değişime neden olduğu belirlenmiştir. MP'nin etki ettiği hücresel mekanizmaları ve metabolik tepkimeleri aydınlatmak için daha fazla çalışmaya ihtiyaç duyulmaktadır.

\section{TEŞEKKÜR}

$\mathrm{Bu}$ çalışmada yardımlarından dolayı Hakan Tosunoğlu'na ve Bursa Uludağ Üniversitesi, Tıp Fakültesi, Farmakoloji Anabilim Dalına teşekkür ederiz.

\section{KAYNAKÇA}

[1] Food and Agriculture Data for Over 245 Countries FAO; [cited:02.03.2020]. 2017. Available from: http://www.fao.org/faostat/en/\#data/RP/visualize.

[2] Tarım ve Orman Bakanlığı, Gıda ve Kontrol Genel Müdürlüğü; [cited:02.03.2020]. 2018. Available from: https://cevreselgostergeler.csb.gov.tr/tarim-ilaci-pestisitkullanimi-i-85834.

[3] Sidhu G.K., Singh S., Kumar V., Dhanjal D.S., Datta S., Singh J. Toxicity, monitoring and biodegradation of organophosphate pesticides: a review, Critical Reviews in Environmental Science and Technology, 49:13 11351187, 2019.

[4] US Environmental Protection Agency, Pesticide Fact Sheet: Methyl parathion. EPA, 1986.

[5] Edwards F.L., Tchounwou P.B. Environmental toxicology and health effects associated with methyl parathion exposure-a scientific review, International Journal of Environmental Research and Public Health, 2:3 430-441, 2005.

[6] Vikrant S. Hepato-renal toxicity-associated with methyl parathion exposure, Hemoglobin (g/dL), 11:12 3-15, 2015.

[7] Vabre P., Gatimel N., Moreau J., Gayrard V., PicardHagen N., Parinaud J., Leandri R.D. Environmental pollutants, a possible etiology for premature ovarian insufficiency: a narrative review of animal and human data, Environmental Health, 16:1 37, 2017.

[8] Guo-Ross S.X., Meek E.C., Chambers J.E., Carr R.L. Effects of chlorpyrifos or methyl parathion on regional cholinesterase activity and muscarinic receptor subtype binding in juvenile rat brain, Journal of toxicology and pharmacology, 1, 2017.

[9] Medina-Díaz I.M., Ponce-Ruiz N., Ramírez-Chávez B., Rojas-García A.E., Barrón-Vivanco B.S., Elizondo G. Bernal-Hernández Y.Y. Downregulation of human paraoxonase 1 (PON1) by organophosphate pesticides in HepG2 cells, Environmental toxicology, 32:2 490-500, 2017.

[10] Khare A., Chhawani N., Kumari K. Glutathione reductase and catalase as potential biomarkers for synergistic intoxication of pesticides in fish, Biomarkers, 24:7 666-676, 2019.

[11] Bartoli S., Bonora B., Colacci A., Niero A., Grilli S. DNA damaging activity of methyl parathion, Research communications in chemical pathology and pharmacology, 71:2 209-218, 1991.

[12] Varga S.I., Matkovics B. Organophosphate effects on antioxidant system of carp (Cyprinus carpio) and catfish (Ictalurus nebulosus), Comparative Biochemistry and Physiology Part C: Pharmacology, Toxicology and Endocrinology, 117:1 83-88, 1997.

[13] Hernandez-Cortes D., Alvarado-Cruz I., Solís-Heredia M.J., Quintanilla-Vega B. Epigenetic modulation of 
Nrf2 and Ogg1 gene expression in testicular germ cells by methyl parathion exposure, Toxicology and applied pharmacology, 346 19-27, 2018.

[14] Gupta V., Bamezai R.N. Human pyruvate kinase M2: a multifunctional protein, Protein science, 19:11 20312044, 2010.

[15] Valentini G., Chiarelli L., Fortin R., Speranza M.L., Galizzi A., Mattevi A. The allosteric regulation of pyruvate kinase A site-directed mutagenesis study, Journal of Biological Chemistry, 275:24 18145-18152, 2000.

[16] Bohringer-Mannheim, Biochemical information, Pyruvate Kinase, 154, 1973.

[17] Bradford M.M. A rapid and sensitive method for the quantitation of microgram quantities of protein utilizing the principle of protein-dye binding, Analytical biochemistry, 72:1-2 248-254, 1976.

[18] Petersen B., Tomerlin J.R., Barraj, L. Pesticide degradation: exceptions to the rule, Food technology (Chicago), 50:5 221-223, 1996.

[19] Dikshit A.K., Pachauri D.C., Jindal, T. Maximum residue limit and risk assessment of beta-cyfluthrin and imidacloprid on tomato (Lycopersicon esculentum Mill), Bulletin of environmental contamination and toxicology, 70:6 1143-1150, 2003.

[20] WHO, International Programme on Chemica Safety, Environmental Health Criteria, 1993.

[21] Extoxnet Methyl parathion pesticide information profile, [cited:02.03.2020]. 1994. Available from: http://pmep.cce.cornell.edu/profiles/extoxnet/haloxyfopmethylparathion/methyl-parathion-ext.html.

[22] Grover I.S., Malhi P.K. Genotoxic effects of some organophosphorous pesticides I. Induction of micronuclei in bone marrow cells in rat, Mutation Research/Genetic Toxicology, 155:3 131-134, 1985.

[23] Celik I., Suzek H. The hematological effects of methyl parathion in rats, Journal of Hazardous Materials, 153:3 1117-1121, 2008.

[24] Uzunhisarcikli M., Kalender, Y. Protective effects of vitamins $\mathrm{C}$ and $\mathrm{E}$ against hepatotoxicity induced by methyl parathion in rats, Ecotoxicology and environmental safety, 74:7 2112-2118, 2011.

[25] Lushchak V.I., Matviishyn T.M., Husak V.V., Storey J.M., Storey, K.B. Pesticide toxicity: a mechanistic approach, EXCLI Journal, 17 1101, 2018.

[26] Dere E., Ari F., Tosunoglu, H. Pyruvate kinase activity in various organs of rats exposed to dinitro-o-cresol and dichlorvos, Acta veterinaria, 58:5-6 439-447, 2008.

[27] Nault R., Fader K.A., Kirby M.P., Ahmed S., Matthews J., Jones A.D., Lunt S.Y., Zacharewski T.R. Pyruvate kinase isoform switching and hepatic metabolic reprogramming by the environmental contaminant 2,3 , 7, 8-tetrachlorodibenzo-p-dioxin, Toxicological Sciences, 149:2 358-371, 2016.

[28] Papadopoulos A.I., Anagnostis A., Lazarou D. Effect of insecticide injection on pyruvate kinase of the insect Tenebrio molitor (Coleopteran), Pesticide biochemistry and physiology, 82:2 115-124, 2005.

[29] Monteiro D.A., De Almeida J.A., Rantin F.T., Kalinin A.L. Oxidative stress biomarkers in the freshwater characid fish, Brycon cephalus, exposed to organophosphorus insecticide Folisuper 600 (methyl parathion), Comparative Biochemistry and Physiology Part C: Toxicology Pharmacology, 143:2 141-149, 2006.

[30] Rezg R., Mornagui B., El-Arbi M., Kamoun A., ElFazaa S., Gharbi N. Effect of subchronic exposure to malathion on glycogen phosphorylase and hexokinase activities in rat liver using native PAGE, Toxicology, 223:1-2 9-14, 2006.

[31] Matin M.A., Husain K., Khan, S.N. Modification of diazinon-induced changes in carbohydrate metabolism by adrenalectomy in rats, Biochemical pharmacology, 39:11 1781-1786, 1990.

[32] Wilkinson J.G., Rajendra W., Oloffs P.C., Banister E.W. Diazinon treatment effects on heart and skeletal muscle enzyme activities, Journal of Environmental Science Health Part B, 21:2 103-113, 1986.

[33] Gray L.R., Tompkins S.C., Taylor E.B. Regulation of pyruvate metabolism and human disease. Cellular and molecular life sciences, 71:14 2577-2604, 2014. 